\title{
Influence of the Occlusal Alteration in the Mandible Morphology of the Gerbil
}

\author{
Influencia de la Alteración Oclusal en la Morfología Mandibular del Jerbo
}

\author{
Fernando José Dias; Richard Honorato de Oliveira; João Paulo Mardegan Issa; Simone Cecílio Hallak Regalo; \\ Valéria O. Pagnano de Souza; Alma Blásida C. E. B. Catirse \& Mamie Mizusaki Iyomasa
}

DIAS, F. J.; OLIVEIRA, R. H.; ISSA, J. P. M.; REGALO, S. C. H.; SOUZA, V. O. P.; CATIRSE, A. B. C. E. B. \& IYOMASA, M. M. Influence of the occlusal alteration in the mandible morphology of the gerbil. Int. J. Morphol., 28(4):1151-1157, 2010.

SUMMARY: Considering the biomechanical aspects, many facts need to be understood on the mandible, to know which effects unilateral occlusal changes may cause on the stomatognathic system. The aim of this study was to analyze the malocclusion by unilateral teeth extraction on the mandible morphology in gerbil. We used 10 gerbils Meriones unguiculatus, young male, weighing around 50-60g, divided into two groups $(n=5)$, an experimental group and control, which evaluated the two hemi-mandibles, with a total of 20 samples which were measured by digital pachymeter. The measures were taken: (1) length and (2) width of the mandible condyle and (3) body height in the region of mandibular 1st molar. Data from these measurements were analyzed using ANOVA and Mann-Whitney test. The results of this study showed a statistically significant difference in the three measures between experimental and control groups. The width of the mandible head (condyle) showed statistical difference between the ipsilateral and contralateral sides to teeth extraction. It was concluded that the mastication modification by unilateral teeth extraction caused an imbalance, promoting not only a modification in the craniofacial growth pattern, but also a harmful effect on the stomatognathic system of the gerbil used as an experimental model in this study.

KEY WORDS: Malocclusion; Morphology; Gerbil.

\section{INTRODUCTION}

The stomatognathic system consists of a heterogeneous group of organs and tissues whose biology is totally interdependent on the performance of their functions. Over the years, the relationship between muscle activity and occlusal changes concerns have been expressed by many professionals involved in oral rehabilitation. Changes observed in the bone belonged to the craniofacial complex in growing rats, caused by masticatory function modification (Beecher \& Corruccini, 1981; Kiliaridis et al., 1985, 1999) and in dental occlusion can promote biomechanical dysfunction on the morphofunctional structure of the head (Baba et al., 1996, 2000).

Muscles play an important role in the normal activity of the stomatognathic system complex, due to the direct relationship with the muscles origin and bone insertions. These locations represent different regions of functional demand, as the shape and area ratio with muscle. However, it will only be possible to understand the biomechanics of the craniofacial skeleton considering it as a dynamic phenomenon.

Studies carried out in experimental animal models revealed that the reduction in masticatory muscles demand can cause interferences in jaws development (Ulgen et al., 1997; Corruccini \& Lee, 1984; Poikela et al., 1997). In agreement, the Bresin et al. (1999) observations showed that the diet consistency change may induce significant differences in the mandible morphology.

Bone studies revealed the onset of bone remodeling by mechanical factors (Bouvier \& Hylander, 1996), compressive loads at specific bone surface exerted by muscular contraction (Teng \& Herring, 1998) and deformation components of the temporomandibular joint masticatory strain (Liu \& Herring, 2000). However, a need exists for in 
vivo studies to understand the biomechanics of occlusal alteration effects on the craniofacial skeleton.

Thus, the purpose of this study was to analyze the effect of unilateral extraction of left upper molars on the mandible morphology (both sides) in the gerbil.

\section{MATERIAL AND METHOD}

Animals. For the present study, we used ten gerbils "Meriones ungiculatus" (Fig. 1A), young male, weighing around $50-60 \mathrm{~g}$, distributed randomly into two groups: experimental $(n=5)$ and control $(n=5)$. We evaluated the hemimandibles, totalizing 20 bone samples.

Animals were located in the animals house of the Faculty of Dentistry of Ribeirão Preto, University of São Paulo (FORP-USP), maintaining five animals per polyethylene cage, measuring $364 \mathrm{~cm} 2$, at controlled room temperature between $22-24^{\circ} \mathrm{C}$, and with timer set to 12 hours of light daily. The animals received food and water ad libitum. The project was approved by the local Ethics Committee on Use of Experimental Animals (CEUA) Campus of Ribeirão Preto-USP (number: 06.1.426.53.6).

Induction of occlusal alteration. The animals of the experimental group were weighed and anesthetized with $2.5 \%$ Tribromoethanol intraperitoneal (ip), $0.25 \mathrm{~g} / \mathrm{kg}$ body weight. After antisepsis of the surgical site with PVPI (polyvinylpyrrolidone), the animals had the left molars extracted with the aid of an anatomical child Hollemback 3S (Fig. 1B), pre-sterilized and plated with polyvinylpyrrolidone. For prophylactic antibiotic method, was administered (pentabiotic for small animals - "Fort Dodge") and a dose of anti-inflammatory, analgesic (diclofenac sodium - "Voltaren" $1 \mathrm{mg} / \mathrm{kg}$ of body weight), both intramuscularly.

Control group was represented by the animals that received the same type of stress for five minutes (average time of teeth extraction), ie, anesthesia and surgery in the supine position with its mouth open with the aid of a space maintainer. They also received the same doses of antiinflammatory, analgesic and antibiotic drugs, with exception of the molars teeth extraction procedure.

Samples for analysis. After 60 days of teeth extraction, the two groups of animals received an overdose of anesthetic urethane $37.5 \%$ intraperitoneal (ip), $3.0 \mathrm{~g} / \mathrm{kg}$ body weight, and were euthanized.
Using surgical instruments, taking care with the aim to not injure the bone surface, the skin of each head was removed (Fig. 1C). Then, the samples were boiled in water during sixty minutes for maceration (Fig. 1D). After cooling, the soft tissues and the remaining brain were eliminated through the foramen magnum using a forceps, brush and scalpel, and in sequence washed in water.

The degreasing of the heads was held in a container with water, hydrogen peroxide to 120 volumes and ammonia hydroxide in proportions of 1:1, 1:20 and 1:50 respectively, which was boiled for thirty minutes. The boiling period was accompanied by the removing the loosened grease and accumulated on the surface and then, the heads were washed again in running water for thirty minutes, while it was rubbed with a small brush to remove some residues adhering to complete cleaning of the mandibles.

Measurements and analysis. Measurements in each hemimandible of both groups of animals were performed using a Mitutoyo digital pachymeter model TN-008M as recommendations Kiliaridis et al. (1999) and Bresin et al. The parameters selected for analysis were:

A. Width of the mandible head - superior view, distance from the medial to the lateral margin of the condyle in its middle portion (Fig. 2A).

B. Length of the mandible head - superior view, distance from the anterior to the posterior margin of the condyle, in its middle portion (Fig. 2B).

C. Height of the mandible body - medial view, distance from the occlusal surface of the first molar to the base of the mandibular body. Using a calibrated pachymeter positioned parallel to the frontal plane and perpendicular to an imaginary line tangent to the mandible base (mandibular plane) (Fig. 2C).

In order to reduce biases and assess the reproducibility and reliability of measurements. All measurements were performed by two different examiners and twice by each examiner. Thus, each measure was collected four times and the average of these four measurements was used for the present study. Among the sequence of the measurements, the device was disconnected and reconnected, and also closed and reset. All measures were tabled for statistical analysis.

Statistical Analysis. The collected data were statistically analyzed, for the length and width of the mandible head (condyle), ANOVA test was used, and the Mann-Whitney test was used to evaluate the height of the mandible body. The selected tests were based on the data distribution of each measure. 

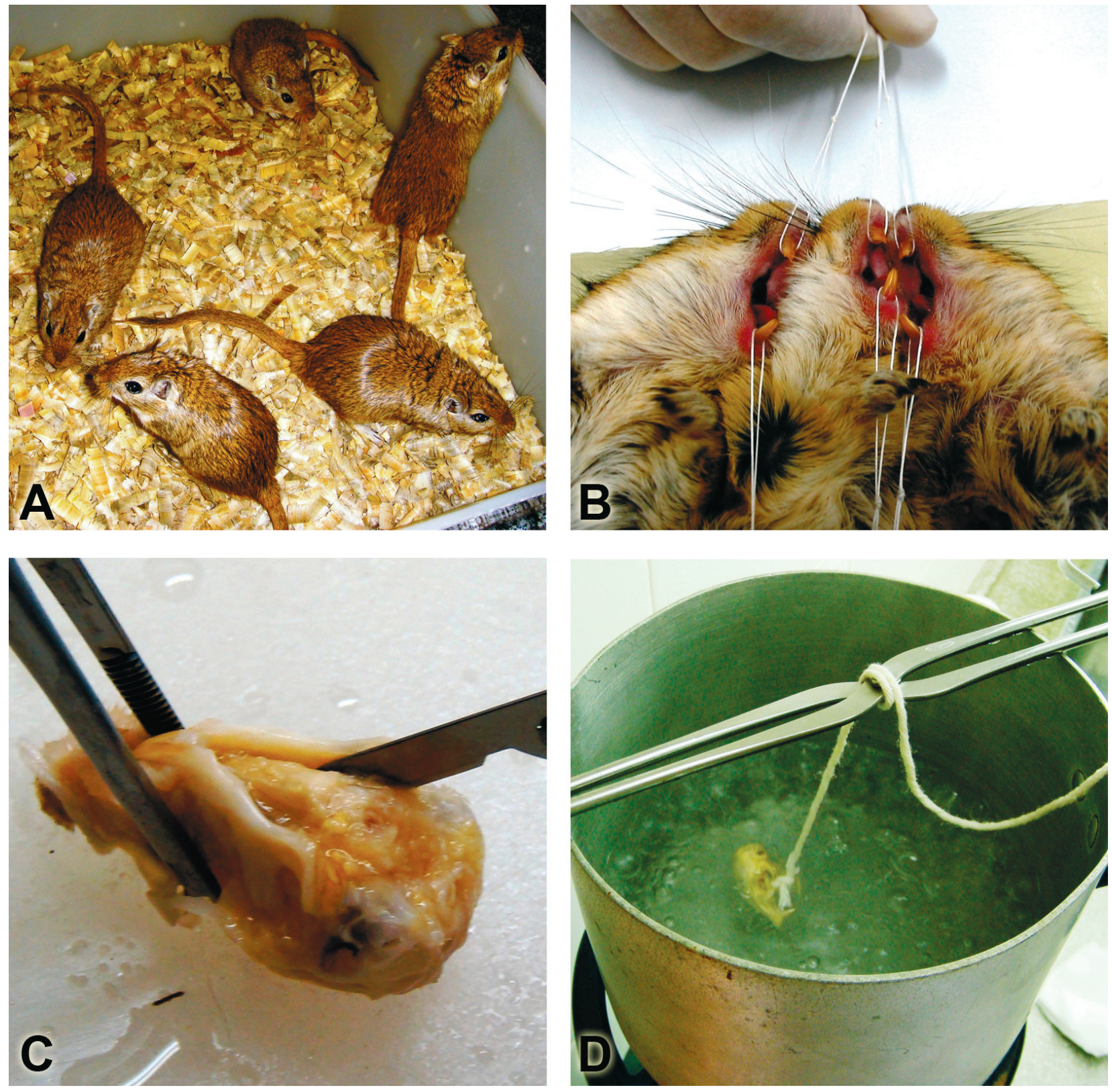

Fig. 1. A. Gerbils used in the study; B. Molar extraction; C. Head without skin; D. Samples Boiled
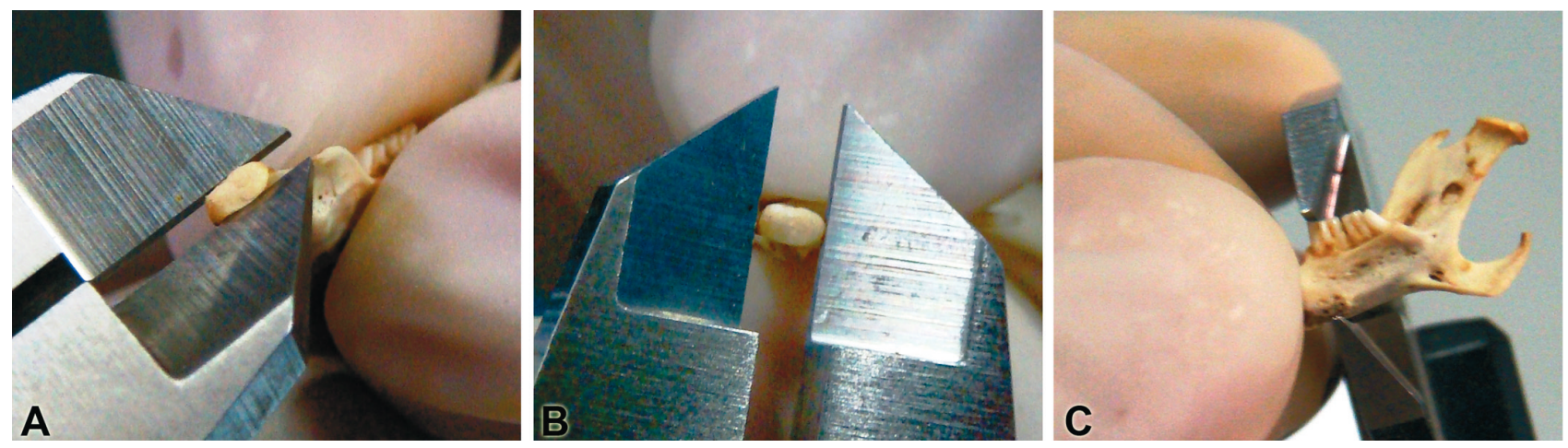

Fig. 2. A. Width of the mandible head; B. Length of the mandible Head; Height of the mandible body 


\section{RESULTS}

The obtained results by measurements were tabulated and may be observed in Table I. The data that is expressed in this work represents the average between the measurements made by the two examiners.

Statistical analysis of the condyle width showed a normal distribution. Thus, through the ANOVA test, statistical difference $(\mathrm{p}<0.05)$ was observed between the experimental and control groups. No statistical difference was observed between the sides, and no interaction was observed between the present data (Table II).

In relation to the condyle length, the submitted data to statistical test using ANOVA revealed statistical difference $(\mathrm{p}<0.05)$, both between experimental and control groups, as between the right and left sides, but no interaction was observed between the data (Table III).

In relation to the mandibular body height, a nonparametric Mann-Whitney test due to non-normal data distribution was used. Regarding this measure, statistically significant difference $(\mathrm{p}<0.01)$ between the experimental and control groups was observed.

Macroscopic measurements of the mandibles. The macroscopic measures showed in the experimental group that the average of measurements taken of the condyle (length and width) of the ipsilateral side of teeth extraction were lower than the contralateral side to the molars. The height of the mandible body in the first molar area was greater on the ipsilateral side compared to the contralateral side to the teeth extraction, and these facts were not found in the control group.

Table I. Means of the measures of the two examiners.

\begin{tabular}{|c|c|c|c|c|c|c|c|}
\hline & & \multicolumn{2}{|c|}{$\begin{array}{l}\text { Width of the mandible } \\
\text { head }\end{array}$} & \multicolumn{2}{|c|}{$\begin{array}{c}\text { Length of the mandible } \\
\text { head }\end{array}$} & \multicolumn{2}{|c|}{$\begin{array}{l}\text { Height of the mandible } \\
\text { body }\end{array}$} \\
\hline & & $\mathbf{R}$ & $\mathbf{L}^{*}$ & $\mathbf{R}$ & $\mathbf{L}^{*}$ & $\mathbf{R}$ & $\mathbf{L}^{*}$ \\
\hline \multirow{5}{*}{$\begin{array}{l}\text { Experimental } \\
\text { Group }\end{array}$} & Gerbil 1 & 1.51 & 1.4625 & 3.2 & 2.945 & 6.0425 & 6.3375 \\
\hline & Gerbil 2 & 1.7025 & 1.5075 & 3.325 & 3.115 & 6.3825 & 6.9025 \\
\hline & Gerbil 3 & 1.605 & 1.555 & 3.105 & 3.03 & 6.065 & 6.3675 \\
\hline & Gerbil 4 & 1.6325 & 1.395 & 3.2625 & 3.0175 & 6.0875 & 6.4475 \\
\hline & Gerbil 5 & 1.7325 & 1.65 & 3.095 & 3.0425 & 6.0225 & 6.6025 \\
\hline \multirow{5}{*}{$\begin{array}{l}\text { Control } \\
\text { Group }\end{array}$} & Gerbil 1 & 1.515 & 1.4325 & 2.9725 & 2.84 & 5.72 & 5.88 \\
\hline & Gerbil 2 & 1.505 & 1.5725 & 3.0075 & 2.6975 & 5.8925 & 5.8825 \\
\hline & Gerbil 3 & 1.3875 & 1.4475 & 3.0125 & 3.0725 & 6.125 & 6.1325 \\
\hline & Gerbil 4 & 1.58 & 1.4625 & 2.8625 & 2.8025 & 5.6425 & 5.5375 \\
\hline & Gerbil 5 & 1.48 & 1.5 & 2.745 & 2.8075 & 5.603 & 5.74 \\
\hline
\end{tabular}

Table II. Means of the width of the mandible head (condyle) - (mm).

\begin{tabular}{lcc}
\hline & \multicolumn{2}{c}{ Width of the mandible head (condyle) } \\
& $\mathbf{R}$ & $\mathbf{L}^{*}$ \\
Experimental Group & 1.6365 & 1.514 \\
Control Group & 1.4935 & 1.483 \\
\hline
\end{tabular}

Table III. Means of the length of the mandible head (condyle) - (mm).

\begin{tabular}{ccc} 
& \multicolumn{2}{c}{ Length of the mandible head (condyle) } \\
& $\mathbf{R}$ & $\mathbf{L}^{*}$ \\
Experimental Group & 3.1975 & 3.03 \\
Control Group & 2.92 & 2.844 \\
\hline
\end{tabular}




\section{DISCUSSION}

The aim of this study was to analyze the effect of unilateral upper teeth extraction on the mandible morphology, both sides, in gerbil.

Schumacher (1999) in a literature review describes four levels at which bone remodeling occurs, these are higher level, related to genetic factors; general level, factors related to primary metabolism, regional, factors related to blood supply; and local level, related to mechanical factors. We suggest a local factor participation in the remodeling process with the aim to explain the present data. Thilander (1995) speculates how to prioritize these factors, for example, the idea that local environmental factors are more relevant for the post-natal facial growth than the general factors.

The unilateral upper incisor extraction in rats promoted changes on the stomatognathic system balance, which is mainly restricted to the site and adjacent areas of the surgical procedure (Yamamoto et al., 1997). In this study, the unilateral teeth extraction promoted changes in the mandible morphology, becoming evident that the stability loss due to unilateral exodontia can determine the biomechanics of stomatognathic system dysfunction, and cause an impact on the bone components.

The Kiliaridis et al. (1999) study showed that the masticatory hypofunction causes a decrease in the condyle dimensions, this result agrees with the present study. Kiliaridis et al. (1985) using rats fed with different diets, one more consistent and another more soft, evaluated the influence of the same situation in the craniofacial growth. A viscerocranial increase was observed in the soft diet group, which is consistent with the growth pattern modification. A decrease in growth rate was also observed in the gonial angle of mandibles in the animals group fed with the soft diet. These findings indicate that the masticatory muscles function influences not only bone turnover in local areas due to the direct action of muscles, but also the pattern of craniofacial growth. This finding again confirms the results of this research, as well as bone abnormalities and craniofacial growth in animals in this study.

Kiliaridis et al. (1996) concluded that an altered masticatory function influences the amount of bone found in certain parts of the mandible, where muscular forces took action on the local voltage marrow. In this study it was observed that the muscle function modification has promoted some changes in bone growth and mandible condyle, because the present macroscopical data revealed a pattern of changes in the three measurements taken in experimental compared to the control groups.

It has been mentioned in the literature that pressures and tensions that contribute to the biomechanical stimuli may promote the formation of cartilage membranes in order to activate bone growth (Ten Cate, 2001). Also, the mechanical force applied on the bone produces mechanical signals on the cells, the type strain of extracellular fluid within the matrix, which may play an important role in bone formation (Owan et al., 1997). Thus, in the present study, in relation to the condyle dimensions, under macroscopic analysis, difference between the ipsilateral and contralateral sides to teeth extraction in the animals of the experimental group was observed, which may be attributed to two factors, one would be the hypofunction of the temporomandibular joint on the operated side, which would decrease the size and hyperfunction of the contralateral side to teeth extraction, promoting an increase in these dimensions. These two factors could explain the present data, which agree with previous data presented in the literature.

Poikela et al. similar to this study, also conducted a study using malocclusion by unilateral teeth extraction, but they used the rabbit as an experimental animal model. These authors observed changes in the mandible, such as length and height decreased on the ipsilateral side of malocclusion, angle changes were also reported. In this way, the authors conclude that the unilateral masticatory function not only causes problems in craniofacial growth, but also promotes a harmful imbalance on the stomatognathic system as a whole. In relation to the height of mandible body, an increase of the height in the molar region was observed, maybe due the fact that the exercise of masticatory function in absence of the antagonists, and in this way, the dental extrusion accompanied by the bone increase in this region. Thus, the unilateral malocclusion molar region causes mandible growth changes that represent a harmful factor for the whole system.

The difference between the sides, ipsilateral and contralateral to teeth extraction, in the operated animals was not observed by statistical analysis, except to the extent of the mandible length.

In relation to the methodology used in this study, we attempted to reduce the errors and also demonstrate the reproducibility and reliability of the method, when 
performing the hemimandibles measurements for more than once and by more than one examiner, and always following viable parameters. This kind of measurement, that is performed directly in the dissecated material using a pachymeter is not classically used in literature, because the photos and radiographs are commonly used in this type of study (Bresin et al.; Kiliaridis et al., 1996; Kiliaridis et al., 1985), but this type of material requires a very sensitive standard, which may represent a factor of bias if not carefully carried out.

This study revealed differences in the measurements of head and body of the mandible between animals not submitted to unilateral molars extraction. This fact suggests that the unilateral occlusal changes can actually cause problems in the balance of stomatognathic system, due to altered biomechanics of mastication, which in this case forces the animals to chew on the right side.

DIAS, F. J.; OLIVEIRA, R. H.; ISSA, J. P. M.; REGALO, S. C. H.; SOUZA, V. O. P.; CATIRSE, A. B. C. E. B. \& IYOMASA, M. M. Influencia de la alteración oclusal en la morfología mandibular del Jerbo.Int. J. Morphol., 28(4):1151-1157, 2010.

RESUMEN: Considerando los aspectos biomecánicos, muchos hechos deben ser entendidos sobre la mandíbula, haciendo necesario comprender cuales son los efectos que pueden causar una alteración oclusal unilateral en el sistema estomatognático. El objetivo de este estudio fue analizar la maloclusión por la extracción de los dientes unilaterales sobre la morfología de la mandíbula en el gerbo. Se utilizaron 10 gerbos Meriones unguiculatus, machos jóvenes, con un peso aproximado de 50-60g, divididos en dos grupos $(n=5)$, un grupo experimental y otro control, en los cuales se evaluaron las dos hemimandíbulas, totalizando 20 muestras que fueron medidas con un caliper digital. Las medidas tomadas fueron: (1) longitud y (2) ancho del cóndilo mandibular, y (3) la altura del cuerpo en la región de los primeros molares mandibulares. Los datos de estas mediciones se analizaron mediante la prueba ANOVA y Mann-Whitney. Los resultados de este estudio mostraron una diferencia estadísticamente significativa en las tres medidas entre los grupos experimental y control. El ancho de la cabeza de la mandíbula (cóndilo) mostró una diferencia estadística entre los lados ipsilaterales y contralaterales a la extracción dentaria. Se concluyó que existe una alteración unilateral de la masticación inducida por la extracción de dientes unilateralmente, causando un desequilibrio y promoviendo no sólo una modificación en el patrón de crecimiento craneofacial, sino también un efecto nocivo obre el sistema estomatognático del gerbo utilizado como modelo experimental en este estudio.

PALABRAS CLAVE: Maloclusión; Morfología; Gerbil.

\section{REFERENCES}

Baba, K.; Ai, M.; Mizutani, H. \& Enosawa, S. Influence of experimental occlusal discrepancy on masticatory muscle activity during clenching. J. Oral Rehabil., 23:55-60, 1996.

Baba, K.; Akishige, S.; Yaka, T. \& Ai, M. Influence of alteration of occlusal relationship on activity of jaw closing muscles and mandibular movement during submaximal clenching. J. Oral Rehabil., 27:793-801, 2000 .

Beecher, R. M. \& Corruccini, R. S. Effects of dietary consistency on craniofacial and occlusal development in the rat. Angle Orthod., 51:61-9, 1981.

Bouvier, M. \& Hylander, W. L. The mechanical or metabolic function of secondary osteonal bone in the monkey Macaca fascicularis. Arch. Oral Biol., 41:941-50, 1996.

Bresin, A.; Kiliaridis, S. \& Strid, K. G. Effect of masticatory function on the internal bone structure in the mandible of the growing rat. Eur. J. Oral Sci., 107:35-44, 1999.

Corruccini, R. S. \& Lee, G. T. Occlusal variation in Chinese immigrants to the United Kingdom and their offspring. Arch. Oral Biol., 29:779-82, 1984.

Kiliaridis, S.; Bresin, A.; Holm, J. \& Strid, K. G. Effects of masticatory muscle function on bone mass in the mandible of the growing rat. Acta Anat. (Basel), 155:2005, 1996.

Kiliaridis, S.; Engström, C. \& Thilander, B. The relationship between masticatory function and craniofacial morphology. I. A cephalometric longitudinal analysis in the growing rat fed a soft diet. Eur. J. Orthod., 7:273$83,1985$.

Kiliaridis, S.; Thilander, B.; Kjellberg, H.; Topouzelis, N. \& Zafiriadis, A. Effect of low masticatory function on condylar growth: a morphometric study in the rat. Am. J. Orthod. Dentofacial Orthop., 116:121-5, 1999. 
DIAS, F. J.; OLIVEIRA, R. H.; ISSA, J. P. M.; REGALO, S. C. H.; SOUZA, V. O. P.; CATIRSE, A. B. C. E. B. \& IYOMASA, M. M. Influence of the occlusal alteration in the mandible morphology of the gerbil. Int. J. Morphol., 28(4):1151-1157, 2010.

Liu, Z. J. \& Herring, S. W. Bone surface strains and internal bony pressures at the jaw joint of the miniature pig during masticatory muscle contraction. Arch. Oral Biol., 45:95$112,2000$.

Owan, I.; Burr, D. B.; Turner, C. H.; Qiu, J.; Tu, Y.; Onyia, J. E.; et al. Mechanotransduction in bone: osteoblasts are more responsive to fluid forces than mechanical strain. Am. J. Physiol., 273:C810-5, 1997.

Poikela, A.; Kantomaa, T. \& Pirttiniemi, P. Craniofacial growth after a period of unilateral masticatory function in young rabbits. Eur. J. Oral Sci., 105:331-7, 1997.

Schumacher, G. H. Regulative and adaptive factors in craniofacial growth. Ann. Anat., 181:9-13, 1999.

Ten Cate, A. R. Histologia Bucal. Desenvolvimento, estrutura e função. $5^{\mathrm{a}}$ ed. Rio de Janeiro, Guanabara Koogan, 1998.

Teng, S. \& Herring, S. W. Compressive loading on bone surfaces from muscular contraction: an in vivo study in the miniature pig, Sus scrofa. J. Morphol., 238:71-80, 1998.

Thilander, B. Basic mechanisms in craniofacial growth. Acta Odontol. Scand., 53:144-51, 1995.

Ulgen, M.; Baran, S.; Kaya, H. \& Karadede, I. The influence of the masticatory hypofunction on the craniofacial growth and development in rats. Am. J. Orthod. Dentofacial Orthop., 111:189-98, 1997.

Yamamoto, M. K.; Novelli, M. D. \& Luz, J. G. Effects of unilateral upper incisor extraction on facial growth of young rats. J. Nihon. Univ. Sch. Dent., 39:191-5, 1997.

\section{Correspondence to:}

Prof. Dra. Mamie Mizusaki lyomasa

Departamento de Morfologia Estomatologia e Fisiologia / FORP-USP

Avenida do Café, s/n

Bairro - Monte Alegre

CEP:14040-904

Ribeirão Preto

SP - BRASIL

Email: mamieiyo@forp.usp.br

Received: 10-07-2010

Accepted: 22-09-2010 
